\title{
Possible Fiscal Policies for Rare, Unanticipated, and Severe Viral Outbreaks
}

\author{
Bill Dupor, Assistant Vice President and Economist
}

onsumer spending in restaurants, travel, leisure, hospitality, and some retail trade sectors is falling because of precautions taken by businesses, households, and governments to reduce the spread of COVID-19. Social distancing and similar actions are reducing demand in some sectors.

The proper fiscal policy response in this situation is not necessarily to try to replace or stimulate that demand, given that the fall in demand is a natural byproduct of the caution. ${ }^{1}$ Rather, the proper policy response may look different from conventional stabilization policy. This essay asks: What should guide a fiscal authority in conducting macroeconomic policy in the event of a severe viral outbreak?

Below I describe some potential fiscal policies that may be appropriate. Two economic principles and one operational principle motivate these potential recommendations.

First, incentivize behavior to align with recognized public health objectives during the outbreak.

Second, avoid concentrating the individual financial burden of the outbreak or the policy response to the outbreak.

Third, implement these fiscal policies as quickly as possible, subject to some efficiency considerations.

At this point, experts are evaluating a wide range of scenarios for the trajectory of the virus in the United States. Some of these scenarios involve a substantial toll on Americans' health. If coordinated macroeconomic policies could help to slow the rate of transmission-by an amount that would reduce overloading U.S. hospitals and help buy time to find a vaccine-so that some of the negative health effects were reduced, this would be a major return on the federal dollars invested in such a program. The pay-off would be in addition to some of the standard business cycle mitigation that motivates standard fiscal interventions.

I describe a $\$ 197.1$ billion proposal with the above issues in mind. Because some observers have advocated for tax rebates in response to COVID-19, and these could prove useful, I also add this component as an option. It increases the overall size of the fiscal intervention to nearly $\$ 350$ billion. $^{2}$ For comparison, the 2009 Recovery Act had a budget impact of about $\$ 815$ billion. $^{3}$
It is well understood that fiscal policy operates with a lag. Parts of a proposal such as the one outlined below might take several weeks to a few months to undergo CBO assessment and budget projections, the federal legislative process, and coordination between state, local, and federal officials to implement those fiscal policies. If the planning process were started now, legislators would have the option to vote for or against federal authorizations depending on whether the policies were deemed necessary up to the moment before a final vote was taken.

\section{Increase Unemployment Insurance Benefit "Replacement Rates" Temporarily and Expand Eligibility To Include Furloughed Workers}

Commuting to and from work, interacting with coworkers, and traveling for work increase the likelihood of viral transmission. Engaging in many "non-market" activitiese.g., time in private with family, cooking meals at home, caring for young and elderly family members at home-is likely to be less risky.

Public health guidance has already encouraged people to stay home in some situations. Or, in economics jargon, to substitute away from market and toward non-market activities. Temporarily increasing unemployment insurance (UI) benefits could encourage this non-market activity even further: Simply, it lowers the relative cost (or price) of engaging in these non-market activities.

UI benefits are often framed as "replacement rates," i.e., the weekly UI benefit amount divided by the typical weekly (pre-unemployment) take-home pay. These rates vary across individuals and U.S. states and over time. ${ }^{4}$ The average replacement rate in the United States is about 45 percent. ${ }^{5}$ Last year, state governments spent $\$ 27.3$ billion on UI benefits. ${ }^{6}$ As a rough calculation, increasing the average replacement rate to 70 percent, with an increased unemployment rate from its current 3.5 percent to 9 percent (as a severe scenario) for nine months would have a government budget impact of $\$ 61.4$ billion. The calculations to arrive at this dollar amount assume that new entrants to the UI rolls receive-on average-the same dollar 
amounts as existing recipients. A potentially more reasonable assumption might be that new recipients received higher benefits, which would be appropriate if those individuals had, on average, higher pre-unemployment earnings than those of existing recipients. I will use a value of $\$ 100$ billion in my analysis for this reason.

Operationally, these dollars would be allocated to state governments-which implement UI programs-from the federal government, which in turn would finance the spending by issuing Treasury debt.

The replacement rate could be increased only for workers in particularly hard-hit sectors. But such assessment and monitoring could likely increase bureaucracy, and bureaucracy slows things down. It might be best for the replacement rates to be increased across the board. States might change the administrative rules of their programs (or statutes, if necessary) to apply UI to "furloughed workers" as well as those unemployed. Then, federally subsidized furloughs would apply to individuals directly through states' existing UI programs. Federally subsidized payments to the quarantined or self-quarantined could also be administered through state UI programs, although potentially at higher replacement rates.

Replacement rate hikes would satisfy the second principle: Avoid concentrating (at least to some extent) the individual financial burden of the outbreak and the policy response to the outbreak.

Businesses experiencing lack of demand, in turn, could lay off/furlough part of their workforce, knowing that the incomes of many of these workers would be made up by (temporarily) more generous UI benefits or a federally subsidized furlough program. "Making payroll" in the face of fallen sales would be less burdensome, and thus it would be less likely for those businesses to run out of cash or otherwise face financing constraints.

Increasing replacement rates could likely be implemented in a few weeks. UI administration systems are already in place in every state. Moreover, with respect to changes that would need to be made to the pre-virus UI system, the federal and some state governments are halfway there already. Last week, the U.S. House of Representatives passed legislation allowing furloughed-and not just unemployed workers-to receive UI benefits. ${ }^{7}$ Also, last week the state of California and other states waived the one-week waiting period to receive unemployment insurance benefits. ${ }^{8}$

One potential downside risk to this policy is that increasing the replacement rate substantially might increase the incentive for workers in unaffected or essential industries to become unemployed and thereafter remain unemployed. High replacement rates and other generous unemployment benefits are sometimes cited as explanations for high per- petual rates of unemployment experienced in some European countries over the past several decades. ${ }^{9}$ Limiting the duration of unemployment benefits, as is done currently in the United States, and returning replacement rates to their pre-crisis values after the economic impact of the virus pandemic has waned could be valuable in mitigating this downside. ${ }^{10}$

\section{Subsidize COBRA Continuation Coverage}

Employer-provided health insurance is commonplace in the United States. Laid off (or furloughed) workers, even if they receive higher UI replacement rates, would (or at least could) lose their health insurance. The federal government already has the COBRA program to allow for continuation of coverage for workers losing their jobs. This program, however, requires worker-paid premiums. These premiums increase the relative cost of engaging in nonmarket activities. To reduce that cost, the federal government might temporarily cover 70 percent of the COBRA premiums for the unemployed or furloughed. Calculating an appropriate size of such a program, even in a rough sense, is difficult at this stage. For a baseline, suppose the allocation were $\$ 25$ billion, which was the value of a similar program implemented under the 2009 Recovery Act. ${ }^{11}$

Once again, because the COBRA program is already in place, administering this part of a fiscal package is unlikely to be slowed by a need to establish a new bureaucracy.

\section{Make Direct Payments to Individuals}

Sometimes they're called cash transfers and tax rebates. By any name, they are an effective way to put money in the hands of most Americans quickly. During normal recessions, the debate among economists is whether households save or consume when they receive these payments. During a severe viral outbreak, how the households use this money seems less relevant. If a recipient banks their transfer check instead of spending it (i.e., to help "stimulate aggregate demand"), this could still provide a buffer of savings against future health or other expenses and possibly reduce their anxiety level if nothing else.

A severe viral outbreak is likely to hit lower wage earners relatively harder than higher earners. Recent research shows that college-educated workers are almost 60 percent more likely to work from home and even more likely to have the ability to sometimes work from home. ${ }^{12}$ Employees that can work from home may face a lower job-loss risk. Lower income workers, who tend to be less educated, are more likely to work hourly and less likely to be able to telecommute. So it might make sense to set maximum income thresholds for cash transfers at lower dollar amounts 
(relative to thresholds from past tax rebate programs) so that lower income individuals can receive higher transfers.

The Economic Stimulus Act of 2008 cost about $\$ 152$ billion and provided payments of at least $\$ 300$ per qualified person ( $\$ 600$ for married couples filing jointly) up to $\$ 600$ (and \$1200) with phase-outs at high incomes. Population growth between 2008 and the present would reduce the size of each household's transfer by about 7 percent, but an amount equal to $\$ 152$ billion might be appropriately sized.

Given the first two principles outlined above, a transfer program receives only so-so marks. A transfer program would not help incentivize Americans toward public health goals. The income effect of the transfer might make it easier for someone to sustain a few weeks away from work, but it would not induce substitution away from market activity. Transfers would also not help avoid concentrating the economic effects of the virus outbreak, apart from a meanstesting component. There is no attempt to target assistance to those most affected.

But the federal government has done this before. It could be done relatively quickly, which satisfies the third principle.

\section{Provide Fiscal Support to State Governments}

During a severe viral outbreak, state governments are likely to be squeezed financially from separate directions: increased Medicaid payments, new costs associated with virus containment, and falling state tax revenue. Projecting the budget impact of declining taxes is a straightforward exercise. In 2018, state governments collected about $\$ 1$ trillion in total taxes. ${ }^{13}$ The $\$ 480$ billion in general sales taxes and gross receipt taxes collected by state governments is of particular importance.

Reduced purchases of some goods and services during a severe outbreak (e.g., meals out and hotel stays) would mean lower tax revenue. A 30 percent decline in this revenue source for six months would create a $\$ 72$ billion budget shortfall. A $\$ 72$ billion state fiscal support program from the federal government would cover this sales tax shortfall.

In addition to the federal-to-state fiscal support I describe here, there would likely be other reasons related to COVID-19 for the federal government to aid state and local governments, such as medical costs and virus containment. Financing these costs in the form of additional grants to states could be considered in a separate Congressional act.

Nearly all states face balanced budget requirements for ongoing expenses. Failure to support states fiscally would put these governments in the difficult position of either raising taxes or cutting back on expenditures. Burdening citizens with additional taxes during a virus outbreak would
Possible Fiscal Policy Responses to Severe Viral Outbreak

\begin{tabular}{lc} 
Fiscal policy action & $\begin{array}{c}\text { Budget impact } \\
(\$, \mathbf{b i l l i o n s})\end{array}$ \\
\hline State government fiscal support & 72.0 \\
\hline Increased UI replacement rate & 100.0 \\
\hline COBRA continuation coverage & 25.1 \\
\hline Penalty-free IRA withdrawals & $\mathrm{NA}$ \\
\hline Direct payments to individuals & 152.0 \\
\hline & 197.1 \\
\hline Total (without tax rebates) & 349.1
\end{tabular}

SOURCE: Author's calculations.

be ill-advised. And, generally speaking, if state government expenditures made sense from a cost-benefit perspective before a viral outbreak, that cost-benefit calculation would likely hold during the outbreak. Thus, it might also be illadvised to cut back on that spending just to satisfy a balanced budget requirement.

In effect, federal dollars for state fiscal support are a kind of workaround for states' borrowing constraints. The federal government has done this before. It could be done relatively quickly.

\section{Another Potential Policy Response}

Penalty-Free Withdrawals from Individual Retirement Accounts

Many Americans hold tax-deferred individual retirement accounts. Individuals can withdraw funds on retirement (and a few other special situations) or any time they wish if they pay a 10 percent penalty. This 10 percent penalty is in addition to the taxes that are due on the withdrawal.

In the event of a severe viral outbreak, the federal government could temporarily remove this 10 percent penalty up to a certain dollar amount and for a preset length of time. Since the initial contribution to the retirement fund was tax deferred, taxes would need to be paid on the withdrawal even if the additional penalty was waived.

For example, setting a $\$ 19,200$ penalty-free maximum IRA distribution for one year would allow someone who has an IRA with sufficient funds, who was at a 28 percent marginal tax rate, to access $\$ 15,000$ after-tax savings as a source of liquidity.

This policy would have no direct federal budget impact because this income support would be self-financed by IRA holders. One could imagine requiring individuals 
accessing such a program to provide proof that funds were used for reasons related to the outbreak or financial hardship indirectly caused by the outbreak; however, this might not be advisable. Such requirements could generate bureaucracy, slow down implementation, and reduce participation as individuals might worry that their particular circumstances would not be covered and thus the 10 percent penalty would not be waived.

One potential question about such a proposal is: If this (possible) economic downturn justifies penalty-free withdrawals, shouldn't fiscal authorities use the policy in all recessions? Perhaps not. Business cycles are semi-regular occurrences. Policymakers might not want households whittling away their IRAs every time there is a "regular recession." Severe viral outbreaks are not semi-regular occurrences. As with several of the above possibilities (e.g., increasing the UI replacement rate), the unorthodox nature of the policy response reflects the unorthodox nature of the shock.

\section{Conclusion}

This essay explains that some nontraditional fiscal policies may be well-suited for a decline in economic activity due to a severe viral outbreak, such as increasing the UI replacement rate and allowing penalty-free IRA withdrawals.

Overall, fiscal policymakers would be wise to assess whether they want to simply follow the standard playbook. Even the phrases "fiscal stimulus" and "aggregate demand" may not be entirely appropriate now: Many people may not want to fly or spend evenings in hotels for the next several months out of caution. Should the goal of fiscal policy be to "stimulate" them to do these things?

The answer to this question relates to the first two principles described in the introduction: incentivizing behavior to align with recognized public health objectives during the outbreak and avoiding concentrating individuals' financial burdens caused by the outbreak.

A parent with a pre-school age child may be better off on federally subsidized furlough (with a livable replacement rate on lost earnings): They would not drop their child off at a day care filled with other children, would not take public transportation to their job, and would not stand in their employer's retail shop with few if any customers. On furlough, this person could self-provide child care, spend time with close family, cook meals at home, and, by doing these things, potentially help reduce the chance of COVID-19 transmission.

\begin{abstract}
Notes
1 Some observers have noted that the current outbreak involves both negative "aggregate supply" and "aggregate demand" components. Those terms may have limited usefulness here. Using those terms, however, the demand aspect may be more important than supply. There are supply-chain disruptions and those could be addressed; however, in two months it may be more likely that new car sales will be down because people are not buying, rather than because cars are not on dealers' lots because producers couldn't acquire parts for production.

2 These options are not intended to be exhaustive. For example, they do not address other possible steps, such as small business loan assistance and programs to alleviate supply chain disruptions.
\end{abstract}

${ }^{3}$ This figure is taken from a February 2015 CBO report entitled "Estimated Impact of the American Recovery and Reinvestment Act on Employment and Economic Output in 2014."

4 They are subject to caps and other restrictions.

5 According to the Department of Labor, https://oui.doleta.gov/unemploy/ui_replacement_rates.asp.

${ }^{6}$ According to the Department of Labor, https://oui.doleta.gov/unemploy/data_summary/DataSum.asp.

7 https://www.wsj.com/articles/mnuchin-says-talks-on-coronavirus-stimulusdeal-going-well-11584106226.

8 https://www.gov.ca.gov/2020/03/12/governor-newsom-issues-new-executive-order-further-enhancing-state-and-local-governments-ability-to-respond-to-covid-19-pandemic/.

${ }^{9}$ See, for example, Ljungqvist and Sargent (2008).

10 Limiting the duration of the high replacement rate policy to a specific number of months or using an unemployment/furlough rate trigger written directly into the enabling federal legislation are two ways to accomplish this.

11 See Joint Committee on Taxation report entitled "Estimated Budget Effects of the Revenue Provisions Contained in the Conference Agreement for H.R. 1, the American Recovery and Reinvestment Tax Act of 2009."

12 See Arbogast, Gascon, and Spewak (2019).

13 This figure comes from the U.S. Census' Annual Survey of State and Local Government Finances.

\section{References}

Arbogast, l.; Gascon, C. and Spewak, A. "Working from Home: More Americans Are Telecommuting," Regional Economist, 2019, Third Quarter.

Ljungqvist, L. and Sargent, T. "Two Questions about European Unemployment," Econometrica, 2008, 76(1), pp. 1-29. 